\title{
ANALYSIS OF INFLUENCE OF PHYSICAL NEEDS MOTIVATION, SECURITY, SOCIAL, SELF-ESTEEM, AND SELF-ACTUALIZATION ON EMPLOYEE JOB SATISFACTION AT PT. SARI TEMBAKAU HARUM KENDAL
}

\author{
Difa Anggraini Suwandi, Suryadi Poerbo², Erika Devie \\ Jurusan Administrasi Bisnis, Politeknik Negeri Semarang, Semarang, Indonesia \\ email: ${ }^{2}$ suryadi poerbo@polines.ac.id
}

\begin{abstract}
The purpose of this research was find out the influence physical need motivation, security, social, self-esteem, and self-actualization on employees jobs saticfaction, and how much was that influenced. The method of analysis in this research used validity test, reliability test, multiple linear regression test, $t$ test, $f$ test, and the coefficient of determination. The result obtained from testing of 5 variable hypothesis $t$-test > t-table 1.(3,477>1,661), 2.(2,496>1,661), 3.(3,370>1,661), 4.(6,266>1,661), 5.(5,103>1,661) so we could conclude that Ha was accepted and Ho was rejected. The results obtained from testing of $f$ test, show that $f$ test $>f$ table (240,820>2,31) so we could conclude that hl was accepted. From the results show the value of the coefficient of determination was 0,924, indicating that the motivation to work had the effect of $92,4 \%$ on job satisfaction and the rest was influenced by other factors which were not examined in this study.
\end{abstract}

Keywords: physical need motivation, security, social, self-esteem, and self-actualization on employees

ANALISIS PENGARUH MOTIVASI KEBUTUHAN FISIK, KEAMANAN, SOSIAL, HARGA DIRI, DAN AKTUALISASI DIRI TERHADAP KEPUASAN KERJA KARYAWAN DI PT. SARI TEMBAKAU HARUM KENDAL

\begin{abstract}
Abstrak
Tujuan penelitian ini adalah untuk mengetahui pengaruh motivasi kebutuhan fisik, keamanan, sosial, harga diri, dan aktualisasi diri terhadap kepuasan kerja karyawan, dan seberapa besar pengaruhnya. Metode analisis dalam penelitian ini menggunakan uji validitas, uji reliabilitas, uji regresi linier berganda, uji t, uji f, dan koefisien determinasi. Hasil yang diperoleh dari pengujian 5 hipotesis variabel t-test> t-tabel 1. (3,477> 1,661), 2. (2,496>1,661), 3. (3,370>1,661), 4. $(6,266>1,661), 5$. (5,103> 1,661) sehingga kita dapat menyimpulkan bahwa Ha diterima dan Ho ditolak. Hasil yang diperoleh dari pengujian $\mathrm{f}$ test, menunjukkan bahwa $\mathrm{f}$ hitung $>\mathrm{f}$ tabel (240,820> 2,31) sehingga dapat kita simpulkan bahwa h1 diterima. Dari hasil penelitian menunjukkan nilai koefisien determinasi adalah 0,924, menunjukkan bahwa motivasi untuk bekerja memiliki pengaruh sebesar $92,4 \%$ pada kepuasan kerja dan sisanya dipengaruhi oleh faktor lain yang tidak diteliti dalam penelitian ini.
\end{abstract}

Kata Kunci: motivasi kebutuhan fisik, keamanan, sosial, harga diri, dan aktualisasi diri pada kepuasan kerja karyawan 


\section{PENDAHULUAN}

PT. Sari Tembakau Harum merupakan salah satu dari 38 mitra produksi sigaret (MPS) produsen rokok PT. HM. Sampoerna, Tbk. Sebagai perusahaan rokok PT. Sari Tembakau Harum memiliki banyak pesaing yang menantang dan mengancam perusahaan. Oleh karena itu, SDM berkualitas merupakan faktor yang mendukung peningkatan perusahaan.

Perusahaan PT. Sari Tembakau Harum sangat memerhatikan peningkatan SDM, namun kenyataannya banyak karyawan yang masih mengalami keterlambatan yang dapat mengakibatkan penurunan perusahaan. Pada PT. Sari Tembakau Harum karyawan yang sering melakukan keterlambatan yaitu karyawan harian. Keterlambatan diduga penyebabnya adalah ketidakpuasan karyawan terhadap perusahaan. Menurut Aamodt (dikutip dalam Mashareen, dkk, 2016:10) karyawan yang tidak puas dalam pekerjaannya dapat menimbulkan berbagai masalah seperti meningkatnya tingkat absensi, turnover karyawan, perilaku kerja pasif dan sebagainya.

Tabel 1 Keterlambatan Karyawan Periode Januari 2017 - Mei 2018

\begin{tabular}{ccc}
\hline Tahun & Bulan & $\begin{array}{c}\text { Total } \\
\text { Keterlambatan }\end{array}$ \\
\hline \multirow{7}{*}{2017} & Januari & 99 Kali \\
& Februari & 87 Kali \\
& Maret & 76 Kali \\
& April & 90 Kali \\
& Mei & 86 Kali \\
& Juni & 79 Kali \\
& Juli & 69 Kali \\
& Agustus & 71 Kali \\
& September & 88 Kali \\
& Oktober & 72 Kali \\
& November & 68 Kali \\
& Desember & 97 Kali \\
& Januari & 101 Kali \\
& Februari & 103 Kali \\
& Maret & 158 Kali \\
& April & 120 Kali \\
& Mei & 136 Kali \\
\hline
\end{tabular}

Sumber: Personalia PT. Sari Tembakau Harum Kendal

Dari tabel 1, dapat disimpulkan bahwa keterlambatan tertinggi pada bulan Maret 2018 terdapat 158 kali keterlambatan karyawan, bulan April 2018 keterlambatan 120 kali, dan bulan Mei 2018 keterlambatan 136 kali. Prianto (2012) memberikan saran dalam penelitiannya bahwa, kebutuhan fisik, sosial, keamanan, penghargaan, dan aktualisasi diri menghasilkan kepuasan kerja yang berdampak positif untuk perusahaan. Perumusan Masalah
Berdasarkan latar belakang yang telah diuraikan, maka masalah yang ada di PT. Sari Tembakau Harum adalah sebagai berikut:

a. Keterlambatan karyawan harian di PT. Sari Tembakau Harum pada tabel cenderung tinggi, hal ini diduga berkaitan dengan ketidakpuasan dalam pemenuhan kebutuhan yang diberikan oleh perusahaan, sehingga masalah tersebut harus diatasi.

b. Maret 2018 keterlambatan sangat tinggi. 
Kalimat pertanyaan penelitian:

a. Bagaimana keterkaitan keterlambatan karyawan dengan ketidakpuasan kerja?

b. Bagaimana pengaruh model peningkatan kepuasan kerja melalui teori motivasi hirarki kebutuhan yaitu kebutuhan fisiologis, keamanan, sosial, harga diri, dan aktualisasi diri terhadap kepuasan kerja karyawan?

Tujuan Penelitian

a. Membuktikan secara empiris apakah pemenuhan kebutuhan Abraham Maslow ada hubungannya dengan tingginya tingkat keterlambatan di PT. Sari Tembakau Harum.

b. Menganalisis pengaruh hirarki pemenuhan kebutuhan terhadap kepuasan kerja pada karyawan harian PT. Sari Tembakau Harum.

Manfaat Penelitian

Manfaat penelitian ini diharapkan bisa menurunkan tingkat keterlambatan karyawan PT. Sari Tembakau Harum yang semula tingkat keterlambatan karyawannya tinggi. Dengan penggunaan teori hirarki kebutuhan Abraham Maslow yang meliputi kebutuhan fisik, keamanan, sosial, harga diri, dan aktualisasi diri, memberikan rekomendasi untuk membenahi konsep kepuasan karyawan pada PT. Sari Tembakau Harum.

Tinjauan Pustaka

Motivasi Kerja

Menurut Putra dan Indrawati (dikutip dalam Puspita, 2018:23) Motivasi adalah kekuatan yang dihasilkan dari keinginan seseorang untuk memuaskan dan memenuhi kebutuhannya.

Proses Motivasi

Menurut Hasibuan (dikutip dalam Puspita, 2018:23) proses motivasi terdiri dari beberapa tahapan proses yang meliputi:

a. Tujuan

Dalam proses motivasi perlu ditetapkan terlebih dahulu tujuan organisasi, baru kemudian para karyawan dimotivasi ke arah tujuan itu.

b. Mengetahui Kepentingan

Hal yang penting dalam proses motivasi adalah mengetahui keinginan karyawan dan tidak hanya melihat dari sudut kepentingan pimpinan atau perusahaan saja.

c. Komunikasi Efektif

Dalam proses motivasi harus dilakukan komunikasi yang baik dengan bawahan. Bawahan harus mengetahui apa yang akan diperolehnya dan syarat apa saja yang harus dipenuhinya supaya insentif tersebut diperolehnya.

d. Integrasi Tujuan

Proses motivasi perlu untuk menyatukan tujuan organisasi dan tujuan kepentingan karyawan. Tujuan organisasi adalah needs complex yaitu untuk memperoleh laba serta perluasan perusahaan, sedangkan tujuan individu karyawan ialah pemenuhan kebutuhan dan kepuasan. Jadi, tujuan organisasi dan tujuan karyawan harus disatukan dan untuk itu penting adanya penyesuaian motivasi.

e. Fasilitas

Manajer penting untuk memberikan bantuan fasilitas kepada organisasi dan individu karyawan yang akan mendukung kelancaran pelaksanaan pekerjaan.

f. Team Work

Manajer harus membentuk team work yang terkoordinasi baik yang bisa mencapai tujuan perusahaan. Team work penting karena dalam suatu perusahaan biasanya terdapat banyak bagian. Maka akan terjadi proses pengulangan dari siklus motivasi dengan perilaku yang berbeda.

\section{Teori Motivasi}

Menurut Hamali (dikutip dalam Puspita, 2018:25), ada beberapa teori utama yang biasa dipakai sebagai pertimbangan dalam menangani masalah pemenuhan kebutuhan dan motivasi personel, salah satu diantaranya yang cukup menonjol adalah Teori Maslow. Maslow (dikutip dalam Jovanovic dan Bozilovic, 2017:99) menyatakan pendapatnya 
"People in the organization runs five primary needs which are hierarchically sorted, so that an individual to meet the needs of more hierarchical be crossed only after satisfying the needs at a lower level. These needs are physiological or existential (needs that each individual has as a biological being - the need for food, water), security needs (the need for the physical and psychological safety protection against external hazards, health care, protection of personal integrity, pension and social insurance), social needs (need for love and friendship and a sense of belonging), the need for respect and self-esteem (need for respect by others, as well as self-esteem, which derives from each other) and the need for actualization (the need for personal development, self-actualization and realization of all their capabilities, talents and full potential)". Teori Maslow adalah mengenai hirarki atau tingkat-tingkat kebutuhan manusia, ia mengungkapkan bahwa pada hakikatnya manusia mempunyai lima kebutuhan yang paling sederhana atau mendesak, hingga kepada tingkat kebutuhan yang canggih. Kebutuhan pertama yaitu kebutuhan yang paling dasar bagi manusia ialah kebutuhan fisiologi seperti makan, minum dan tempat berlindung (rumah). Kebutuhan berikutnya adalah kebutuhan akan keselamatan mencakup pengakuan senioritas, berserikat, dan jaminan pekerjaan. Kemudian kebutuhan untuk merasa diakui dan dihargai keberadaannya atau diterima oleh kelompok dan lingkungannya. Lalu kebutuhan estim seperti status, titel, pengakuan, dan promosi. Dan yang terakhir atau yang tertinggi adalah aktualisasi diri seperti pemenuhan keinginan dan pencapaian terhadap sesuatu yang tinggi. Kebutuhan-kebutuhan diatas bila tidak terpenuhi bagi karyawan akan menimbulkan ketegangan, frustasi dan menurunkan motivasi kerjanya.

\section{Jenis-Jenis Motivasi}

Menurut Husnan (2008:204) Pada garis besarnya motivasi yang diberikan bisa dibagi menjadi dua yaitu motivasi positif dan motivasi negatif. Motivasi positif adalah proses untuk mencoba mempengaruhi orang lain agar menjalankan sesuatu yang kita inginkan dengan cara memberikan kemungkinan untuk mendapatkan "hadiah". Motivasi negatif adalah proses untuk mempengaruhi seseorang agar mau melakukan sesuatu yang kita inginkan, tetapi teknik dasar yang digunakan adalah lewat kekuatan ketakutan. Penelitian ini menggunakan kuisioner dengan pernyataan motivasi positif.

Prinsip-prinsip dalam Memotivasi Kerja Karyawan

Menurut Hamali (dikutip dalam Puspita, 2018:29) yaitu:

a. Prinsip Partisipasi, dalam memotivasi kerja, karyawan perlu diberikan kesempatan ikut berpartisipasi dalam menentukan tujuan yang akan dicapai oleh pimpinan.

b. Prinsip Komunikasi, pemimpin mengkomunikasikan segala sesuatu yang berhubungan dengan usaha pencapaian tugas, dengan informasi yang jelas, karyawan akan lebih mudah dimotivasi kerjanya.

c. Prinsip Mengakui Andil Bawahan, pemimpin mengakui bahwa bawahan (karyawan) mempunyai andil di dalam usaha pencapaian tujuan. Karyawan akan lebih mudah dimotivasi kerjanya dengan pengakuan tersebut.

d. Prinsip Pendelegasian Wewenang, pemimpin yang memberikan otoritas atau wewenang kepada karyawan untuk sewaktu-waktu dapat mengambil keputusan terhadap pekerjaan yang dilakukannya, akan membuat karyawan yang bersangkutan menjadi termotivasi untuk mencapai tujuan yang diharapkan oleh pemimpin.

e. Prinsip Memberi Perhatian, pemimpin memberikan perhatian terhadap apa yang diinginkan karyawan bawahan, akan memotivasi karyawan bekerja apa yang diharapkan oleh pemimpin. 
Kepuasan Kerja

Menurut Basna (2016) kepuasan kerja pada dasarnya sesuatu yang bersifat individual. Setiap individu memiliki tingkat kepuasan yang berbeda-beda sesuai dengan sistem nilai yang berlaku pada dirinya.

Teori Kepuasan Kerja

Menurut Wibowo (2010:503) teori kepuasan kerja antara lain:

1) Two-factor Theory

Teori dua factor merupakan teori kepuasan kerja yang menganjurkan bahwa kepuasan dam ketidakpuasan merupakan bagian dari kelompok variabel yang berbeda, yaitu motivators dan hygiene factor.

2) Value Theory

Menurut konsep teori ini kepuasan kerja terjadi pada tingkatan dimana hasil pekerjaan diterima individu seperti diharapkan. Semakin orang banyak menerima hasil semakin puas.

Faktor-Faktor yang Mempengaruhi Kepuasan Kerja

Menurut Mangkunegara (2001:120) faktorfaktor yang mempengaruhi kepuasan kerja adalah :

a. Faktor pegawai, yaitu kecerdasan (IQ), kecakapan khusus, umur, jenis kelamin, kondisi fisik, pendidikan, pengalaman kerja, masa kerja, kepribadian, emosi, cara berpikir, persepsi, dan sikap kerja.

b. Faktor pekerjaan, yaitu jenis pekerjaan, struktur organisasi, pangkat (golongan), kedudukan, mutu pengawasan, jaminan finansial, kesempatan promosi jabatan, interaksi sosial, dan hubungan kerja.

Mangkunegara (2001:120) menyimpulkan faktor-faktor yang mempengaruhi kepuasan kerja, yaitu;

1) Faktor Psikologis, merupakan faktor yang berhubungan dengan kejiwaan, yang meliputi minat, ketentraman dalam kerja, sikap terhadap kerja, bakat dan keterampilan

2) Faktor Sosial, merupakan faktor yang berhubungan dengan interaksi sosial antar karyawan maupun karyawan dengan atasan.

3) Faktor Fisik, merupakan faktor yang berhubungan dengan kondisi fisik karyawan, meliputi jenis pekerjaan, pengaturan waktu dan waktu istirahat, perlengkapan kerja, keadaan karyawan, umur, dan sebagainya.

4) Faktor Finansial, merupakan faktor yang berhubungan dengan jaminan serta kesejahteraan karyawan, yang meliput sistem dan besarnya gaji, jaminan sosial, macam-macam tunjangan, fasilitas yang diberikan, promosi dan sebagainya.

Faktor-faktor kepuasan kerja menurut Mangkunegara (2001:120) dapat menjadi bahan untuk pembuatan pernyataan dalam instrument penelitian.

Indikator Kepuasan Kerja

Menurut Luthans (dikutip dalam Sekartini, 2016:65)

1) Kepuasan pada Pekerjaan itu sendiri (Satisfaction with the Work Itself. Pekerjaan yang dilakukan oleh seorang karyawan akan dapat menghasilkan kepuasan kerja, motivasi intern, prestasi kerja yang tinggi, tingkat kemangkiran yang rendah dan tingkat labour turn over yang rendah.

2) Kepuasan dengan gaji (Satisfaction with Pay) Kepuasan pada gaji merupakan hal yang bersifat multi dimensional. Hal ini berarti bahwa kepuasan karyawan bukan hanya terletak pada jumlah gaji/upah semata.

3) Kepuasan pada Promosi (satisfaction with Promotion) Kesempatan untuk dipromosikan merupakan hal yang dapat memberikan kepuasan pada karyawan. Kesempatan ini merupakan bentuk imbalan yang bentuknya berbeda dengan imbalan yang lain.

4) Kepuasan pada Supervisi

(Satisfaction with Supervision) Supervisi merupakan salah satu hal yang cukup penting sebagai sumber kepuasan kerja. 
Kepuasan terhadap supervisi sangat berkaitan dengan gaya kepemimpinan supervise.

5) Kepuasan pada Rekan Kerja

(Satisfaction with Coworkes) Rekan kerja dapat menjadi sumber kepuasan karyawan, manakala antar karyawan diberi kesempatan untuk berinteraksi satu sama lain.

Pengukuran Kepuasan Kerja

Menurut Robbins (dalam Wibowo, 2010:510)

Terdapat dua macam pendekatan secara luas dipergunakan untuk melakukan pengukuran kerja, yaitu sebagai berikut:

1) Single global rating

Meminta individu merespon atas satu pertanyaan, seperti dengan mempertimbangkan semua hal, seberapa puas Anda dengan pekerjaan Anda? Responden menjawab antara "Highly Satisfied" dan "Highly Dissatisfied".

2) Summation Score

Mengidentifikasikan elemen kunci dalam pekerjaan dan menanyakan perasaan pekerja tentang masing-masing elemen. Faktor spesifik yang diperhitungkan adalah: sifat pekerjaan, supervice, upah.

Hubungan Antara Motivasi Kerja Dan Kepuasan Kerja

Wibowo (2010:506) menunjukkan bahwa terdapat hubungan positif dan signifikan antara motivasi dengan kepuasan kerja. Karena kepuasan dengan supervisi juga mempunyai korelasi signifikan dengan motivasi. Manajer secara potensial dapat meningkatkan motivasi kerja melalui berbagai usaha untuk meningkatkan kepuasan kerja.

Hipotesis Penelitian

a. Pemenuhan Kebutuhan Fisik berpengaruh signifikan terhadap kepuasan kerja

Kebutuhan ini dapat berupa kebutuhan akan makanan, kebutuhan seksual, dan kebutuhan biologis lainnya. Menurut Prianto (2012) terdapat pengaruh yang positif antara variabel X1 terhadap variabel
Y, yang artinya semakin baik variabel Kebutuhan Fisiologis maka semakin baik Kepuasan Kerja. Penelitian ini dapat dirumuskan Hipotesis, H1: Kebutuhan Fisik (X1) berpengaruh signifikan terhadap kepuasan kerja (Y).

b. Pemenuhan Kebutuhan Keamanan berpengaruh signifikan terhadap kepuasan kerja

Kebutuhan keamanan untuk kepastian di masa yang akan datang seperti, pesangon hari tua (BPJS), jaminan sosial dan lain sebagainya. Jadi kebutuhan keamanan bukan sekedar untuk merasa aman dari berbagai gangguan fisik maupun mental. Menurut Prianto (2012) terdapat pengaruh yang positif antara variabel $\mathrm{X} 2$ terhadap variabel $\mathrm{Y}$, yang artinya semakin baik variabel Kebutuhan Keamanan maka semakin baik Kepuasan Kerja. Penelitian ini dapat dirumuskan Hipotesis, H2: Kebutuhan Keamanan (X2) berpengaruh signifikan terhadap kepuasan kerja (Y).

c. Pemenuhan Kebutuhan Sosial berpengaruh signifikan terhadap kepuasan kerja

Kebutuhan sosial merupakan kebutuhan untuk berinteraksi dan diterima oleh lingkungan sosial. Menurut Prianto (2012) terdapat pengaruh yang positif antara variabel X3 terhadap variabel $Y$, yang artinya semakin baik variabel Kebutuhan Sosial maka semakin baik Kepuasan Kerja. Penelitian ini dapat dirumuskan Hipotesis, H3: Kebutuhan Sosial (X3) berpengaruh signifikan terhadap kepuasan kerja (Y).

d. Pemenuhan Kebutuhan Harga Diri berpengaruh signifikan terhadap kepuasan kerja

Kebutuhan ini dapat berupa penghargaan dari atasan, dari lingkungan sekitar, maupun adanya kejelasan atas penghargaan bagi tenaga kerja berprestasi. Menurut Prianto (2012) terdapat pengaruh yang positif antara variabel $\mathrm{X} 4$ terhadap variabel $\mathrm{Y}$, yang artinya semakin baik variabel Kebutuhan Harga Diri maka semakin baik Kepuasan Kerja. Penelitian 
ini dapat dirumuskan Hipotesis, H4: Kebutuhan Harga Diri (X4) berpengaruh signifikan terhadap kepuasan kerja (Y).

e. Pemenuhan Kebutuhan Aktualisasi Diri berpengaruh signifikan terhadap kepuasan kerja

Kebutuhan ini untuk menempatkan diri individu dalam lingkungan dan untuk pengembangan diri. Kebutuhan ini dapat berupa kebutuhan pertumbuhan, kebutuhan pencapaian potensi seseorang, kebutuhan pemenuhan diri sendiri, dan kebutuhan dorongan untuk menjadi apa yang dia mampu capai. Menurut Prianto (2012) terdapat pengaruh yang positif antara variabel X5 terhadap variabel $\mathrm{Y}$, yang artinya semakin baik variabel Kebutuhan Aktualisasi Diri maka semakin baik Kepuasan Kerja. Penelitian ini dapat dirumuskan Hipotesis, H5: Kebutuhan Aktualisasi Diri (X5) berpengaruh signifikan terhadap kepuasan kerja (Y).

\section{METODE PENELITIAN}

Populasi

Karyawan Harian PT. Sari Tembakau Harum yang berjumlah 99 karyawan, dengan teknik pengambilan sampel menggunakan sensus atau sampling jenuh menurut Sugiyono (2014:122).

\section{Jenis Data Menurut Sumbernya}

1) Data Primer

Menurut Bungin (2013:128) Data primer adalah data yang diperoleh langsung dari sumber data pertama atau primer, diamati dan dicatat untuk pertama kalinya. Data ini diperoleh dari pembagian kuisioner yang diisi oleh karyawan PT. Sari Tembakau Harum.

2) Data Sekunder

Data yang bukan diusahakan sendiri pengumpulannya oleh peneliti. Marzuki (2010:55) Data ini diperoleh dari buku-buku yang berhubungan dengan motivasi kerja dan kepuasan kerja data yang diperoleh dari PT. Sari Tembakau Harum antara lain, struktur organisasi dan gambaran umum perusahaan.
Jenis Data Menurut Sifatnya

Menurut Marzuki (2010:55) ada 2 jenis data yaitu:

1) Kuantitatif

Data kuantitatif adalah data yang bisa dihitung atau diukur, misalnya besar gaji, banyak absensi, lama belajar. Data yang diperoleh antara lain hasil kuisioner berupa lama bekerja, usia, dan skor tanggapan angket PT. Sari Tembakau Harum.

2) Kualitatif

Data yang diukur secara tak langsung seperti aktivitas, keterampilan, sikap. Data yang diperoleh antara lain adalah struktur organisasi, profil perusahaan, job diskripsi di PT. Sari Tembakau Harum.

Uji Validitas

Suatu kuesioner dikatakan valid jika pertanyaan pada kuesioner mampu untuk mengungkapkan sesuatu yang akan diukur oleh kuesioner tersebut. Menurut Ghozali (2016:54) suatu item pernyataan dikatakan valid jika $r$ hitung lebih besar daripada $r$ tabel.

Uji Reliabilitas

Suatu kuesioner dikatakan reliabel atau handal jika jawaban seseorang terhadap pernyataan adalah konsisten atau stabil dari waktu ke waktu.

Menurut Ghozali (2016:48) suatu konstruk atau variabel dikatakan reliabel jika memberikan nilai Cronbach Alpha $>0.70$

Analisis Regresi Linear Berganda

$$
\begin{gathered}
Y=a+b_{1} X_{1}+b_{2} X_{2}+b_{3} X_{3}+b_{4} X_{4}+ \\
b_{5} X_{5}+e
\end{gathered}
$$

Keterangan:

$\mathrm{Y}=$ Variabel dependen (nilai yang diprediksikan)

$\mathrm{a}=$ Konstanta (nilai $\mathrm{Y}$ bila $\mathrm{X}=0$ )

$\mathrm{b}=$ Koefisien regresi

$\mathrm{X}_{1}, \mathrm{X}_{2}, \mathrm{X}_{3}, \mathrm{X}_{4}, \mathrm{X}_{5}=$ Variabel independen 
Uji Asumsi Klasik

a. Uji Multikolinieritas

Menurut Ghozali (2013:105) uji multikolonieritas bertujuan untuk menguji apakah model regresi ditemukan adanya korelasi antar variabel bebas (independen).

b. Uji Heteroskedastisitas

Menurut Ghozali (2013:139) uji heteroskedastisitas bertujuan menguji apakah dalam model regresi terjadi ketidaksamaan variance dari residual satu pengamatan ke pengamatan yang lain.

c. Uji Normalitas Data

Menurut Ghozali (2016:154) uji normalitas bertujuan untuk menguji apakah dalam model regresi, variabel pengganggu atau residual memiliki distribusi normal.

Koefisien Determinasi

Koefisien determinasi $\left(\mathrm{R}^{2}\right)$ untuk mengukur besarnya persentase pengaruh semua variabel independen dalam model regresi terhadap variabel dependennya (Purwanto \& Sulistyastuti, 2007:195).

\section{Uji Hipotesis}

a. Uji Signifikansi simultan (uji-F)

Uji $F$ digunakan untuk menunjukkan apakah semua variabel independen yang dimasukkan dalam persamaan atau model regresi secara bersamaan berpengaruh terhadap variabel dependen (Purwanto \& Sulistyastuti, 2007:194).

Kriteria pengambilan keputusannya adalah: H0 diterima jika Fhitung < Ftabel pada $\alpha=$ $5 \%$

H0 ditolak jika Fhitung > Ftabel pada $\alpha=5 \%$

b. Uji Signifikansi Parsial (Uji-T)

Uji t (Uji Parsial) digunakan untuk melihat seberapa jauh pengaruh variabel independen secara individual terhadap variabel dependennya (Purwanto \& Sulistyastuti, 2007:193)

Kriteria pengambilan keputusan:

Ho diterima jika $\mathrm{t}$ hitung $<\mathrm{t}$ tabel pada $\alpha=$ $5 \%$

Ha diterima jika $\mathrm{t}$ hitung $>\mathrm{t}$ tabel pada $\alpha=$ $5 \%$

\section{HASIL ANALISIS PEMBAHASAN}

Pengujian kuesener

Dari pengujian data primer, dihasilkan semua butir pertanyaan/pernyataan adalah validi, Menurut Ghozali (2016:48) suatu konstruk atau variabel dikatakan reliabel jika memberikan nilai Cronbach Alpha >0,70 Dari hasil analisis data, dihasilkan bahwa semua variable reliable.

Tabel 2 Output SPSS Regresi

\begin{tabular}{|c|c|c|c|}
\hline \multirow{2}{*}{ Variabel } & \multicolumn{2}{|c|}{$\begin{array}{l}\text { Koefisien Tidak } \\
\text { Standar }\end{array}$} & \multirow{2}{*}{ Signifikar } \\
\hline & B & $\begin{array}{c}\text { Standar } \\
\text { Kesalahan }\end{array}$ & \\
\hline (Konstanta) & 2,421 & 1.168 & 0,041 \\
\hline K. Fisik & 0,458 & 0,132 & 0,001 \\
\hline K. Keamanan & 0,366 & 0,147 & 0,014 \\
\hline K. Sosial & 0,725 & 0,215 & 0,001 \\
\hline K. Harga Diri & 0,806 & 0,129 & 0,000 \\
\hline K. Aktualisasi Diri & 0,585 & 0,115 & 0,000 \\
\hline
\end{tabular}

Sumber: Data primer yang diolah, 2018

Persamaan Regresi

Hasil pengolahan dan komputerisasi menunjukkan persamaan regresi berganda,
$\mathrm{Y}=2,421+0,458 \mathrm{X}_{1}+0,366 \mathrm{X}_{2}+0,725 \mathrm{X}_{3}+$ $0,806 X_{4}+0,585 X_{5}$ 
$\mathrm{a}=2,421$ artinya jika variabel kebutuhan fisik (X1), kebutuhan keamanan (X2), kebutuhan sosial (X3), kebutuhan harga diri (X4), dan kebutuhan aktualisasi diri $(\mathrm{X} 5)=0$, maka nilai kepuasan kerja sebesar 2,421. Dalam hal ini jika kebutuhan fisik, kebutuhan keamanan, kebutuhan sosial, kebutuhan harga diri, kebutuhan aktualisasi diri bernilai 0,000 maka kepuasan kerja akan meningkat $2,42 \%$

$\mathrm{b}_{1}=0,458$ merupakan nilai koefisien regresi variabel kebutuhan fisik terhadap variabel kepuasan kerja. Artinya Ada kecenderungan kenaikan kebutuhan fisik (X1), maka kepuasan kerja akan mengalami peningkatan sebesar 0,458 atau 45,8\% koefisien bernilai positif artinya antara kebutuhan fisik dan kepuasan kerja berpengaruh positif. Kenaikan kebutuhan fisik akan mengakibatkan kenaikan kepuasan kerja.

$\mathrm{b}_{2}=0,366$ merupakan nilai koefisien regresi

variabel kebutuhan keamanan terhadap variabel kepuasan kerja. Artinya Ada kecenderungan kenaikan kebutuhan keamanan (X2), maka kepuasan kerja akan mengalami peningkatan sebesar 0,366 atau $36,6 \%$ koefisien bernilai positif artinya antara kebutuhan keamanan dan kepuasan kerja berpengaruh positif. Kenaikan kebutuhan keamanan akan mengakibatkan kenaikan kepuasan kerja.

$\mathrm{b}_{3}=0,725$ merupakan nilai koefisien regresi variabel kebutuhan sosial terhadap variabel kepuasan kerja. Artinya ada kecenderungan kenaikan kebutuhan sosial (X3), maka kepuasan kerja akan mengalami peningkatan sebesar 0,725 atau 72,5\% koefisien bernilai positif artinya antara kebutuhan sosial dan kepuasan kerja berpengaruh positif. Kenaikan kebutuhan sosial akan mengakibatkan kenaikan kepuasan kerja

$\mathrm{b}_{4}=0,806$ merupakan nilai koefisien regresi variabel kebutuhan harga diri terhadap variabel kepuasan kerja. Artinya Ada kecenderungan kenaikan kebutuhan harga diri (X4), maka kepuasan kerja akan mengalami peningkatan sebesar 0,806 atau $80,6 \%$ koefisien bernilai positif artinya antara kebutuhan harga diri dan kepuasan kerja berpengaruh positif. Kenaikan kebutuhan harga diri akan mengakibatkan kenaikan kepuasan kerja.

$\mathrm{b}_{5}=0,585$ merupakan nilai koefisien regresi variabel kebutuhan aktualisasi diri terhadap variabel kepuasan kerja. Artinya ada kecenderungan kenaikan kebutuhan aktualisasi diri (X5), maka kepuasan kerja akan mengalami peningkatan sebesar 0,585 atau 58,5\% koefisien bernilai positif artinya antara kebutuhan aktualisasi dan kepuasan kerja berpengaruh positif. Kenaikan kebutuhan aktualisasi akan mengakibatkan kenaikan kepuasan kerja.

$\mathrm{e}=$ standar eror yang digunakan adalah $5 \%$, menunjukkan tingkat fluktuasi

Uji Asumsi Klasik

a. Uji Multikolonieritas

Tabel 3 Pengujian Multikolonieritas

\begin{tabular}{cc}
\hline Toleransi & VIF \\
\hline 0,185 & 5,410 \\
0,236 & 4,230 \\
0,301 & 3,320 \\
0,348 & 2,875 \\
0,331 & 3,021 \\
\hline
\end{tabular}

Sumber: Data primer yang diolah, 2018

Dari tabel 3, terlihat bahwa tidak ada variabel yang memiliki nilai VIF $\geq 10$ sehingga dari hal-hal tersebut di atas dapat disimpulkan bahwa tidak terdapat multikolonieritas antar variabel bebas dalam model regresi. 
b. Uji Heteroskedastisitas Menurut Ghozali (2013:139) tidak terjadi heteroskedastisitas karena penyebaran titik (scatterplot) menyebar diatas dan dibawah angka 0 pada sumbu $Y$.

\section{Scatterplot}

Dependent Variable: Kepuasan Kerja Karyawan

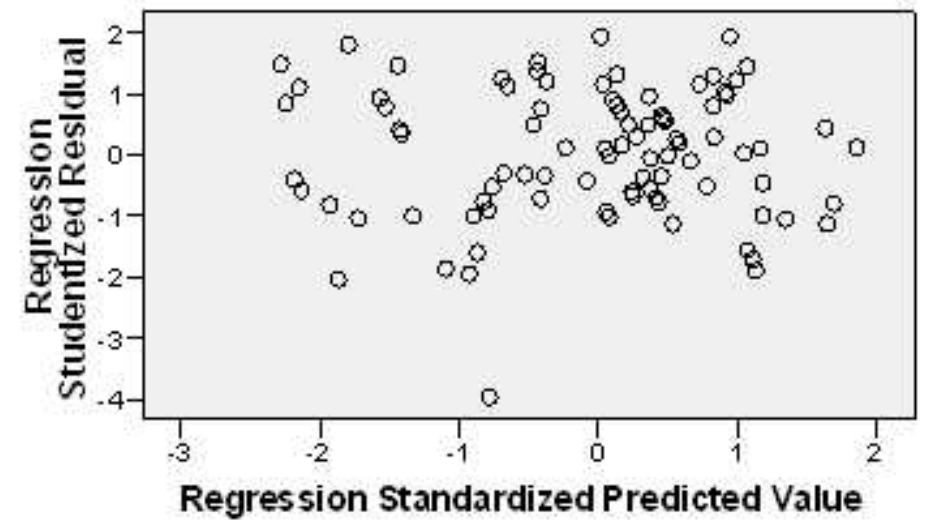

Gambar 1 Scatterplot

c. Uji Normalitas

\section{Histogram}

\section{Dependent Variable: Kepuasan Kerja Karyawn}

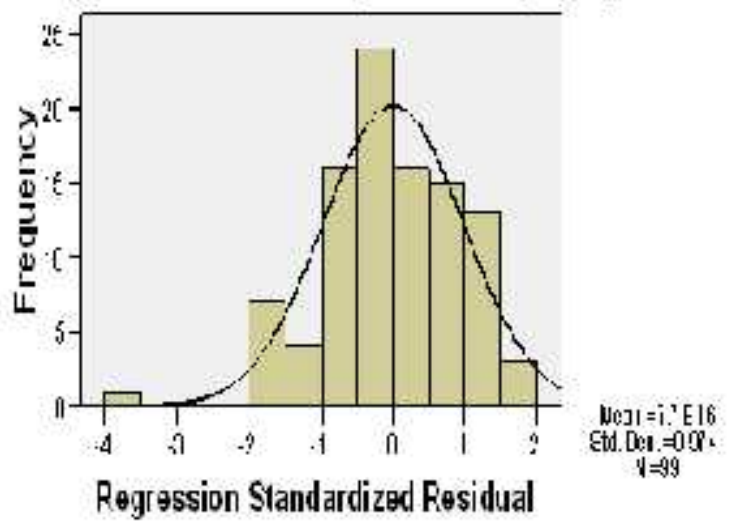

Gambar 2 Histogram 


\section{Normal P.P Plot of Regression Standardized Residual}

\section{Dependent Variable: Kepuasan Kerja Karyawan}

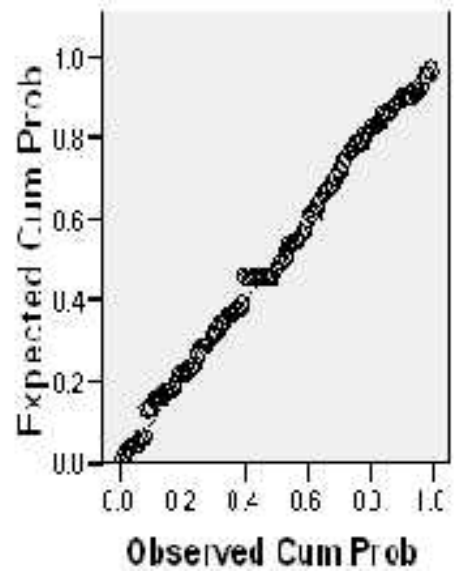

Gambar 3 Normal P-P Plot of Regression Standardized Residual

Grafik normal probability plot menunjukkan bahwa data menyebar di sekitar garis diagonal dan menurut Ghozali (2013:163) jika data menyebar disekitar garis diagonal atau grafik histogramnya menunjukkan pola distribusi normal, maka model regresi memenuhi asumsi normalitas.

Tabel 4 Hasil Analisis Regresi Kepuasan Karyawan: (X1, X2, X3, X4, X5)

\begin{tabular}{lcccc}
\hline \multicolumn{1}{c}{ Variabel } & $\mathrm{t}$ hitung & $\mathrm{t}$ tabel & Signifikansi & Ket \\
\hline K. Fisik & 3,477 & 1,661 & 0,001 & Sig. \\
K. Keamanan & 2,496 & 1,661 & 0,014 & Sig. \\
K. Sosial & 3,370 & 1,661 & 0,001 & Sig. \\
K. Harga Diri & 6,266 & 1,661 & 0,000 & Sig. \\
K. Aktualisasi Diri & 5,103 & 1,661 & 0,000 & Sig. \\
\hline
\end{tabular}

Sumber: Data primer yang diolah, 2018

Uji t (t-test)

Dari tabel 4 dapat disimpulkan

1) Uji hipotesis pengaruh kebutuhan fisik (X1) terhadap kepuasan karyawan (Y)

Dari hasil perhitungan didapat nilai thitung sebesar 3,477 Apabila dilihat pada tabel $t$ dengan $a=5 \%$ di dapat ttabel sebesar 1,661 ini berarti bahwa thitung > ttabel $\quad(3,477>1,661) \quad$ dan nilai signifikansi 0,001 dengan demikian Ho ditolak sedangkan Ha diterima. Artinya dari hasil penelitian diyakini bahwa ada pengaruh signifikan dari variabel kebutuhan fisik terhadap kepuasan karyawan.

2) Uji Hipotesis pengaruh kebutuhan kemanan (X2) terhadap kepuasan karyawan (Y)

Dari hasil penghitungan didapat nilai thitung sebesar 2,496 Apabila dilihat pada tabel $t$ dengan $a=5 \%$ di dapat ttabel sebesar 1,661.

Ini berarti bahwa thitung >ttabel $(2,496>1,661)$ dan nilai signifikansi 0,014 dengan demikian Ho ditolak sedangkan Ha diterima. Artinya ada hasil penelitian diyakini bahwa ada pengaruh 
signifikan dari variabel kebutuhan keamanan terhadap kepuasan karyawan

3) Uji hipotesis pengaruh kebutuhan sosial (X3) terhadap kepuasan karyawan (Y)

Dari hasil perhitungan didapat nilai thitung sebesar 3,370 Apabila dilihat pada tabel $t$ dengan $a=5 \%$ di dapat ttabel sebesar 1,661

Ini berarti bahwa thitung >ttabel $(3,370>1,661)$ dan nilai signifikansi 0 , 001 dengan demikian Ho ditolak sedangkan Ha diterima.

Artinya dari hasil penelitian diyakini bahwa ada pengaruh signifikan dari variabel kebutuhan sosial terhadap kepuasan karyawan.

4) Uji hipotesis pengaruh kebutuhan harga diri (X4) terhadap kepuasan karyawan (Y)

Dari hasil penghitungan didapat nilai thitung sebesar 6,266 Apabila dilihat pada tabel $t$ dengan $a=5 \%$ di dapat ttabel sebesar 1,661. Ini berarti bahwa thitung > ttabel $(6,266>1,661) \quad$ dan nilai signifikansi 0,000 dengan demikian Ho ditolak sedangkan $\mathrm{Ha}$ diterima. Artinya dari hasil penelitian diyakini bahwa ada pengaruh signifikan dari variabel kebutuhan harga diri terhadap kepuasan karyawan

5) Uji hipotesis pengaruh kebutuhan aktualisasi diri (X5) terhadap kepuasan karyawan (Y)

Dari hasil penghitungan didapat nilai thitung sebesar 5,103 apabila dilihat pada tabel $\mathrm{t}$ dengan $\mathrm{a}=5 \%$ di dapat ttabel sebesar 1,661.

Ini berarti bahwa thitung >ttabel $(5,103>1,661)$ dan nilai signifikansi 0,000 dengan demikian Ho ditolak sedangkan Ha diterima.

Artinya dari hasil penelitian diyakini bahwa ada pengaruh signifikan dari variabel kebutuhan aktualisasi diri terhadap kepuasan karyawan.

Tabel 5 Uji F Anova

\begin{tabular}{cccccc}
\hline Model & $\begin{array}{c}\text { Jumlah } \\
\text { Kuadrat }\end{array}$ & Df & $\begin{array}{c}\text { Rata- } \\
\text { Rata } \\
\text { Kua-drat }\end{array}$ & F & Sig. \\
\hline Regresi & 5026,125 & 5 & 1005,225 & 240,820 & 0,000 \\
Sisa & 388,198 & 93 & 4,174 & & \\
Total & 5414,323 & 98 & & & \\
\hline
\end{tabular}

Sumber: Data primer yang diolah, 2018

Uji f (f-test)

a. Merumuskan hipotesis

$\mathrm{H}_{0}=$ Tidak ada pengaruh signifikan antara kebutuhan fisik, kebutuhan kemanan, kebutuhan sosial, kebutuhan harga diri, kebutuhan aktualisasi diri secara bersama sama terhadap kepuasan kerja di PT. Sari Tembakau Harum Kendal.

$\mathrm{H}_{1}=$ Ada pengaruh signifikan antara kebutuhan fisik, kebutuhan keamanan, kebutuhan sosial, kebutuhan harga diri, kebutuhan aktualisasi diri secara bersama-sama terhadap kepuasan kerja di PT. Sari Tembakau Harum Kendal b. Tingkat signifikansi

Tingkat signifikansi menggunakan $\alpha=$ $5 \%$ (signikansi 5\% atau 0,05 adalah ukuran standar yang sering digunakan dalam penelitian).

c. Menentukan f-hitung

Berdasarkan tabel diperoleh $\mathrm{f}_{-}$hitung sebesar 240,820

d. Menentukan $\mathrm{f}_{\text {-tabel }}$ Dengan menggunakan tingkat keyakinan $95 \%, \alpha=5 \%$, df pembilang (jumlah variabel-1) $=5$, dan df penyebut (njumlah variabel) atau 99-6 = 93, kemudian hasil diperoleh untuk $\mathrm{f}_{- \text {tabel }}$ sebesar 2,31. (Sarjono, 2012:109). Nilai 
$\mathrm{F}_{\text {tabel }}$ ini diperoleh berdasarkan data nilai $\mathrm{F}_{\text {tabel }}$ (lihat lampiran).

e. Kesimpulan

Karena f-hitung $>\mathrm{f}_{\text {-tabel }}$ yaitu 240,820>2,31, maka dapat disimpulkan bahwa $\mathrm{H}_{1}$ diterima, artinya ada pengaruh secara signifikan antara kebutuhan fisik, kebutuhan keamanan, kebutuhan sosial, kebutuhan harga diri, kebutuhan aktualisasi diri secara bersama-sama terhadap kepuasan kerja di PT. Sari Tembakau Harum Kendal.

Tabel 6 Koefisien Determinasi

\begin{tabular}{cccc}
\hline Model & $\mathrm{R}$ & $\begin{array}{c}\mathrm{R} \\
\text { Kuadrat }\end{array}$ & $\begin{array}{c}\text { R Kuadrat } \\
\text { Penyesuaian }\end{array}$ \\
\hline 1 & 0,963 & 0,928 & 0,924 \\
\hline
\end{tabular}

Sumber: Data primer yang diolah, 2018

Koefisien determinasi

Berdasarkan Tabel 6 tampilan output SPSS model Summary besarnya adjusted R2 adalah 0,924 hal ini berarti variabel kebutuhan fisik, keamanan, sosial, harga diri, aktualisasi diri mempunyai pengaruh terhadap kepuasan karyawan sebesar $92,4 \%$. Sedangkan sisanya sebesar 7,6\% merupakan variabel lain yang tidak diteliti dalam penelitian ini.

Implikasi Hasil Penelitian

Penelitian ini mendukung penelitian Kusuma (2015) “Analisis Pengaruh Motivasi Hirarki Kebutuhan Terhadap Kepuasan Kerja Karyawan Pada PT. Pelabuhan Indonesia III (Persero) Cabang Semarang" dengan hasil secara positif dan signifikan motivasi hirarki kebutuhan (fisik, keamanan, sosial, penghargaan, dan aktualisasi diri) mempengaruhi kepuasan kerja karyawan. Pada penelitian ini telah diperoleh hasil persamaan regresi berganda $\mathrm{Y}=2,421+$ $0,458 X_{1}+0,366 X_{2}+0,725 X_{3}+0,806 X_{4}+$ $0,585 \mathrm{X}_{5}$, Artinya variabel independen yakni kebutuhan fisik (X1), kebutuhan keamanan (X2), kebutuhan sosial (X3), kebutuhan harga diri (X4) dan kebutuhan aktualisasi diri (X5) berpengaruh signifikan dan positif terhadap kepuasan kerja, artinya apabila kebutuhan fisik (X1), kebutuhan keamanan (X2), kebutuhan sosial (X3), kebutuhan harga diri (X4) dan kebutuhan aktualisasi diri (X5) mengalami peningkatan, maka akan berdampak dengan meningkatnya kepuasan kerja karyawan harian PT. Sari Tembakau Harum Kendal. Sebaliknya apabila kebutuhan fisik (X1), kebutuhan keamanan (X2), kebutuhan sosial (X3), kebutuhan harga diri (X4) dan kebutuhan aktualisasi diri (X5) mengalami penurunan maka kepuasan kerja karyawan harian PT. Sari Tembakau Harum Kendal juga akan menurun. Dari hasil koefisien regresi yang didapat menunjukkan variabel kebutuhan penghargaan $(\mathrm{X} 4=0,806)$ menjadi faktor terbesar yang mempengaruhi tingkat kepuasan kerja, kemudian kebutuhan keamanan $(\mathrm{X} 2=0,366)$ menjadi faktor terendah yang mempengaruhi kepuasan kerja karyawan harian PT. Sari Tembakau Harum Kendal

Berdasarkan hasil dari uji F dapat disimpulkan bahwa seluruh variabel independen (kebutuhan fisik, kebutuhan keamanan, kebutuhan sosial, kebutuhan harga diri, dan kebutuhan aktualisasi diri) berpengaruh positif terhadap kepuasan kerja. Disamping itu secara simultan hasil dari uji hipotesis menunjukkan bahwa secara bersama-sama seluruh variabel independen (kebutuhan fisik, kebutuhan keamanan, kebutuhan sosial, kebutuhan harga diri, dan kebutuhan aktualisasi diri) berpengaruh terhadap kepuasan kerja, karena $\mathrm{F}_{\text {hitung }}$ sebesar 240,820 lebih besar dari $F_{\text {tabel }}$ yaitu sebesar 2,31.

Dari lima variabel yang mempengaruhi kepuasan kerja karyawan harian PT. Sari Tembakau Harum Kendal, variabel yang 
paling dominan adalah variabel penghargaan berdasarkan uji t. Variabel penghargaan mempunyai nilai $t_{\text {hitung }}(6,266)>t_{\text {tabel }}(1,661)$, paling besar dibandingkan dengan variable lainnya. Variabel terendah yaitu keamanan dengan nilai $t_{\text {hitung }}(2,496)>t_{\text {tabel }}(1,661)$. Hal ini berarti bahwa variable harga diri harusnya lebih diperhatikan lagi oleh PT. Sari Tembakau Harum Kendal, karena memiliki pengaruh yang lebih dominan terhadap tingkat kepuasan kerja karyawan harian PT. Sari Tembakau Harum Kendal.

Nilai koefisien determinasi dapat dilihat dari Adjusted $R$ Square sebesar 0,924, hal ini berarti $92,4 \%$ variabel kepuasan kerja dapat dijelaskan oleh lima variabel yaitu variable kebutuhan fisik, kebutuhan keamanan, kebutuhan sosial, kebutuhan harga diri, dan kebutuhan aktualisasi diri, sedangkan sisanya $7,6 \%(100 \%$ - 92,4\%) dipengaruhi oleh variabel lain yang tidak diteliti dalam penelitian ini.

Dari perhitungan uji validitas, item-item dalam tiap dimensi variabel menghasilkan $r$ hitung sebesar 0,963, sedangkan $r$ table sebesar 0,1975 pada $a=5 \%$. Berdasarkan hasil tersebut maka dapat disimpulkan bahwa kuesioner yang digunakan dalam penelitian ini valid, sehingga kuesioner dapat digunakan sebagai sumber mengumpulan data dalam model regresi ini, karena $r_{\text {hitung }}$ lebih besar daripada $r_{\text {tabel. }}$.

Dari hasil uji asumsi klasik (uji normalitas, uji heterokedastisitas, dan multikolonieritas) menunjukkan tidak ada variabel yang memiliki ketiga penyakit regresi tersebut.

Dengan demikian, asumsi-asumsi normalitas, heterokedastisitas, dan multikolonieritas dalam model regresi dapat dipenuhi dalam penelitian ini.

\section{SIMPULAN DAN SARAN}

a. Kebutuhan fisik berpengaruh terhadap kepuasan kerja karyawan dengan nilai koefisien regresi 0,458 dan signifikan 0,001 .

b. Kebutuhan keamanan berpengaruh terhadap kepuasan kerja karyawan dengan nilai koefisien 0,366 dan signifikan 0,014.

c. Kebutuhan sosial berpengaruh terhadap kepuasan kerja karyawan dengan nilai koefisien 0,725 dan signifikan 0,001

d. Kebutuhan harga diri berpengaruh terhadap kepuasan kerja karyawan dengan nilai koefisien 0,806 dan signifikan 0,000

e. Kebutuhan aktualisasi diri berpengaruh terhadap kepuasan kerja karyawan dengan nilai koefisien 0,585 dan signifikan 0,000.

Kebutuhan fisik, keamanan, sosial, harga diri, dan aktualisasi diri secara simultan berpengaruh terhadap kepuasan kerja karyawan dengan persamaan $\mathrm{Y}=2,421+$ $0,458 \mathrm{X}_{1}+0,366 \mathrm{X}_{2}+0,725 \mathrm{X}_{3}+0,806$ $\mathrm{X}_{4}+0,585 \mathrm{X}_{5}$

f. Variabel yang memiliki pengaruh paling dominan terhadap kepuasan kerja karyawan adalah kebutuhan harga diri dengan nilai beta sebesar 0,806, sedangkan variabel paling rendah yang mempengaruhi adalah keamanan sebesar 0,366 . Hal ini berarti bahwa variabel kebutuhan harga diri lebih berpengaruh meningkatkan kepuasan kerja karyawan dibanding dengan variabel lainnya.

g. Dari hasil penelitian yang dilakukan terhadap 99 responden, persepsi responden dalam instrumen penelitian dapat diketahui bahwa sebagian besar responden menyatakan kecenderungan setuju kecil sebesar 48,23\%, hal ini dapat disimpulkan bahwa karyawan merasa kepuasan yang diberikan perusahaan cenderung belum memuaskan. Dan dapat diketahui terbuktinya secara empiris antara penelitian ini dan pengaruhnya terhadap keterlambatan.

Saran

Berdasarkan pembahasan dan kesimpulan di atas, maka saran yang dapat dijadikan pertimbangan bagi PT. Sari Tembakau Harum yaitu: 
Perusahaan direkomendasikan untuk meningkatkan berbagai kebutuhan yang diperlukan oleh karyawan, dari hasil regresi menunjukkan bahwa semua variabel bernilai positif, yang artinya jika kebutuhan karyawan dipenuhi maka akan terjadi peningkatan kepuasan kerja. Hal ini diharapkan dapat memperbaiki konsep kepuasan karyawan dalam PT. Sari Tembakau Harum Kendal, karena apabila kepuasan kerja karyawan dapat naik maka produktivitas naik.

Dari hasil pengolahan regresi berganda nilai koefisien kebutuhan harga diri adalah yang terbesar dibandingkan yang lain hal ini dapat menjadi bahan rekomendasi untuk perusahaan dalam meningkatkan konsep kepuasan karyawan melalui kebutuhan harga diri, sebagai contoh memberi penghargaan non finansial kepada karyawan yang tingkat kehadirannya baik atau tidak ada ijin. Sebaiknya satu bulan sekali perusahaan mengadakan program pertemuan dengan semua kayawan terkait untuk mengumumkan karyawan yang berprestasi sekaligus memberi penghargaan yang berupa bingkisan untuk karyawan yang berprestasi, dan karyawan akan dinaikkan menjadi mandor apabila terus meningkatkan prestasinya. Berdasarkan hal tersebut diharapkan dapat menekan keterlambatan.

\section{DAFTAR PUSTAKA}

Basna, Frengky. 2016. Analisis Gaya Kepemimpinan, Kepuasan Kerja, Komitmen Organisasi dan Kompetensi terhadap Kinerja Pegawai. Riset Bisnis dan Manajemen, vol. 4, No. 3.

Bungin, Burhan. 2013. Metodologi Penelitian Sosial \& Ekonomi. Jakarta: Prenada.

Ghozali, Imam. 2013. Aplikasi Analisis Multivariete Dengan Program IBM SPSS 21. Semarang: Undip.

--------. 2016. Aplikasi Analisis Multivariete Dengan Program IBM SPSS 23. Semarang: Undip.

Husnan, Suad dan Heidjrachman. 2008. Manajemen Personalia Edisi 4. Yogyakarta:BPFE-Yogyakarta.
Jovanovic dan Bozilovic. 2017. The influence of management of human resources on motivation and job saticfaction.Jurnal Internasional.Fakultas Ekonomika Universitas UNION Nikola-Tesla, Belgrade.

Kusuma, Ivanovich Perdana. 2015.Analisis Pengaruh Motivasi Hirarki Kebutuhan terhadap Kepuasan Kerja Karyawan pada PT. Pelabuhan Indonesia III (Persero) Cabang Semarang.Skripsi.Jurusan Administrasi Bisnis Polines, Semarang.

Mangkunegara, Anwar Prabu. 2001. Manajemen Sumber Daya Manusia Perusahaan. Bandung: PT Remaja Rosdakarya

Marzuki: 2010. Metodologi riset. Yogyakarta: BPFE-UII

Mashareen, dkk, 2016. "Survei Tingkat Kepuasan Kerja Karyawan PT X Melalui Alat Ukur Job Satisfaction Scale". Riset Bisnis dan Manajemen, vol. 3, Maret 2016 hal 9-22.

Prianto, Kusnul. 2012. Pengaruh Motivasi Terhadap Kepuasan Kerja Pada Perusahaan Kontraktor di Malang.Jurnal Ilmu Teknik, vol. 9 No. 3.

Purwanto, Erwan Agus dan Dyaah Ratih Sulistyastuti. 2007. Metode Penelitian Kuantitatif Untuk Administrasi Publik. Yogyakarta: Gava Media.

Puspita, Tati. 2018. Pengaruh Komitmen Organisasi, Disiplin Kerja dan Motivasi terhadap Kinerja Karyawan pada Perusahaan Daerah Air Minum Kabupaten Brebes.Skripsi.Fakultas Ekonomi dan Bisnis Universitas Muhammadiyah, Purwokerto.

Sekartini, Ni Luh. 2016. Pengaruh Kemampuan Kerja, Disiplin Kerja, Motivasi Kerja terhadap Kepuasan Kerja dan Kinerja Karyawan Administrasi. Jurnal Ekonomi \& Bisnis, vol. 3 No.2.

Sugiyono. 2014. Metode Penelitian Bisnis.Bandung: Alfabeta Bandung

Wibowo: 2010. Manajemen Kinerja. Jakarta: PT Rajagrafindo Persada 
Suwandi, dkk/AdBis 20 (1): 21 - 36 